\title{
PENGEMBANGAN INSTRUMEN PENILAIAN KETERAMPILAN TEKNIK FOREHAND DAN BACKHAND DRIVE TENIS MEJA PADA ATLET USIA DINI
}

\section{DEVELOPMENT OF TECHNICAL SKILLS ASSESSMENT INSTRUMENT FOREHAND AND BACKHAND DRIVE TABLE TENNIS AT EARLY AGE ATHLETES}

\author{
Verandita Rihtiana, Tomoliyus \\ Prodi Ilmu Keolahragaan PPs UNY, Universitas Negeri Yogyakarta \\ vera_pingpong@yahoo.com, tomoliyus@yahoo.com
}

\begin{abstract}
Abstrak
Penelitian ini bertujuan untuk mengembangkan instrumen penilaian keterampilan teknik forehand dan backhand drive tenis meja pada atlet usia dini. Penelitian ini menggunakan metode penelitian dan pengembangan, dengan langkah-langkah pengembangan sebagai berikut: (1) pengumpulan informasi di lapangan, (2) melakukan analisis terhadap informasi yang dikumpulkan, (3) mengembangkan produk awal (draf model), (4) validasi ahli dan revisi, (5) uji coba skala kecil dan revisi, (6) uji coba skala besar dan revisi, (7) pembuatan produk final. Subjek penelitian atlet tenis meja usia dini. Analisis data untuk uji validitas dilakukan dengan CVR (content validity ratio) dan reliabilitas dengan menggunakan Alpha Crobanch. Penelitian ini menghasilkan buku panduan instrumen penilain keterampilan teknik forehand dan backhand drive tenis meja untuk atlet pemula yang didalamnya berisi petunjuk penggunaan, lembar tugas siswa, pedoman penilaian, rubrik penilaian, serta tabel penyekoran, yang memiliki validitas yang tinggi (1) dan reliabilitas yang tinggi, forehand drive sikap awal: $r=0,975$, pelaksanaan: $r=0,961$, gerak lanjutan: $r=0,955$. Backhand drive sikap awal: $r=$ 0,961 , pelaksanaan $\mathrm{r}=0,974$, gerak lanjutan: $\mathrm{r}=0,989$.
\end{abstract}

Kata Kunci: instrumen penilaian teknik forehand dan backhand drive, tenis meja

\begin{abstract}
This research purposed to produce instrument model skills assessment forehand and backhand techniques drive at early age table tennis athlets. Research method that used is research and development $(R \& D)$, did with some research development step: (1) collection of information in the field, (2) do an analysis about information that collected, (3) developing the beginning product, (4) specialist validation and revision, (5) trial for small scale and revision, (6) trial for big scale and revision, (7) production of final product. Research subject is table tennis athletes early age.Data analysis for validation trial did by CVR (content validation ratio) and reliability with alpha crobanch. This research produces technical skills assessment guidebook for forehand and backhand tennis table for athletes early age that contains instruction for using, student task sheet, assessment guide lines, assessment rubric, and also scoring table that have high validation (l) and high reliability, the beginning to forehand drive attitude: $r=0.975$. Implementation: $r=0.961$. Follow through: $r=0.955$. The beginning to backhand drive attitude: $r=0.961$.Implementation: $r=0.974$. Follow through: $r=$ 0.984 .
\end{abstract}

Keywords: techniques of assessent instrument, forehand and backhand drive, table tennis. 


\section{Pendahuluan}

Dalam suatu pembinaan tenis meja banyak faktor yang dibutuhkan dalam proses pembinaan. Proses pembinaan tenis meja yang baik yaitu apabila didukung oleh adanya peralatan dan sarana yang cukup, metode latihan yang efektif, program latihan yang efektif, proses pemanduan bakat yang efektif, evaluasi atau penilaian hasil latihan, dana yang cukup, kemampuan pelatih, menejemen serta organisasi yang baik.

Program latihan yang baik menjadi salah satu penentu dalam keberhasilan setiap cabang olahraga, latihan yang terprogram dapat menghasilkan proses latihan yang baik. Keberhasilan dalam proses latihan sangat tergantung dari kualitas latihan yang dilaksanakan, karena proses latihan merupakan paduan kegiatan dari beberapa faktor pendukung terutama oleh keadaan dan kemampuan pelatih serta olahragawan tersebut (Sukadiyanto, 2002, p.4).

Selain program latihan, evaluasi juga mempunyai peranan yang penting dalam proses pembinaan atlet. Program latihan seperti apapun tidak dapat terlepas dari evaluasi, karena dengan adanya evaluasi pelatih akan lebih mudah memberikan masukan, mengkoreksi, memperbaiki kesalahan, dan menilai keberhasilan dari proses latihan yang dilakukan oleh atlet.

Pada kenyataanya di dalam proses latihan tidak dilakukan dengan evaluasi, kalaupun ada evaluasi itu dilakukan oleh para pelatih tenis meja tanpa menggunakan instrumen yang baku, hal tersebut dikarenakan belum adanya instrumen tenis meja yang menilai teknik forehand dan backhaand drive tenis meja yang baku.proses latihan dan penilaian saling berkaitan sehingga jika dalam proses latihan tidak ada instrumen penilaian yang digunakan untuk dasar evaluasi maka proses latihan kutang optimal.

Penilaian adalah suatu proses untuk mengabil keputusan dengan menggunakan informasi yang diperoleh melalui pengukuran hasil belajar baik yang menggunakan tes maupun non tes (Zainul dkk, 2001, p.20). Penilaian mempunyai arti yang lebih luas dari pengukuran, karena pengukuran sebenarnya hanya merupakan suatu langkah atau tindakan yang perlu diambil dalam proses penilaian yang dilakukan. Penilaian mempunyai pengertian tentang proses memberikaan atau menentukan nilai kepada suatu objek tertentu berdasarkan suatu kriteria tertentu (Sudjana, 2005, p.3).
Tujuan utama dari penilaian harus memberikan umpan balik kepada guru dan siswa, karena itu, menentukan nilai seharusnya menjadi alasan untuk melakukan penilaian. Manfaat penilaian adalah untuk dapat mengetahui seberapa besar kemampuan seseorang, dan dengan adanya suatu penilaian maka akan lebih mudah untuk dilakukan suatu evaluasi sehingga kemampuan yang dimiliki dapat diperbaiki dan ditingkatkan. Tujuan dalam penilaian, yaitu menginformasikan keputusan tentang pengalaman belajar dan melaporkan apa yang telah dicapai (Harlen, 2007, p.15).

Penelitian pengembangan ini bertujuan untuk; Memperoleh indikator sesuai teknik forehand drive tenis meja usia dini, memperoleh indikator sesuai teknik backhand drive tenis meja usia dini, memperoleh seperangkat instrumen penilaian teknik forehand drive tenis meja usia dini yang valid dan reliabel, memperoleh seperangkat instrumen penilian teknik backhand drive tenis meja usia dini yang valid dan reliabel, memperoleh keefektifan instrumen penilaian teknik backhand dan forehand drive tenis meja bagi atelt usia dini.

Instrumen penilaian dalam pelaksanaan pembelajaran digunakan untuk memperoleh data dan informasi sebagai dasar untuk menentukan tingkat keberhasilan siswa dalam penguasaan suatu kompetensi. Instrumen penilaian adalah suatu alat yang digunakan untuk mengukur, misalnya mengukur ranah kognitif dapat tertulis secara lisan, sedangkan untuk menilai ranah psikomotorik dilakukan dengan tes perbuatan atau dengan yang lainya.

Iinstrumen dikatakan baik apabila memenuhi beberapa kriteria: (1) relevan dalam pengumpulan data sesuai dengan tujuan penilaian, (2) ada kseimbangan proporsi pengukuran secara multidimensional, (3) bisa digunakan secara efisien, (4) adanya keobjektifan gambaran kejujuran penilaian (tidak luas), (5) memperlihatkan kekonsistenan pengukuran, (6) menggambarkan kejujuran penilaian (tidak bias), (7) secara spesifik mengukur aspek yang dipelajari, (8) menggambarkan tingkat kesulitan yang ditunjukan oleh keterampilan, pengetahuan, dan kemampuan individu yang dinilai, (9) bisa membedakan level kemampuan individu, (10) tidak mengukur kecepatan (Payne, 2003, pp.2030).

Sebuah instrumen yang baik untuk digunakan dalam sebuah penilaian memiliki persyaratan penting yang harus dimiliki dalam sebuah instrumen tersebut. Instrumen yang baik 
harus memenuhi dua persyaratan penting yang valid dan reliabel. Validitas adalah suatu ukuran yang menunjukkan tingkat-tingkat kevalidan atau kesahihan suatu instrument (Arikunto, 2002, p.144). Reliabilitas adalah konsistensi tes, artinya sebuah tes yang dapat diandalkan harus mempunyai hasil kurang lebih sama tanpa mempedulikan jumlah waktu yang diberikan (Miller, 2002, p.59). Reliabilitas diperoleh dengan cara yang sama dengan proses mencari validitas empiris yaitu dengan menghitung koefisien korelasi. Namun koefisien reliabilitas tidak dapat digunakan untuk keperluan validasi karena apa yang reliabel belum tentu valid tetapi apa yang valid selalu reliabel.

\section{Metode Penelitian}

Tujuan dari penelitian ini adalah; memperoleh indikator sesuai teknik forehand drive tenis meja usia dini, memperoleh indikator sesuai teknik backhand drive tenis meja usia dini, memperoleh seperangkat instrumen penilaian teknik forehand drive tenis meja usia dini yang valid dan reliabel, memperoleh seperangkat instrumen penilian teknik backhand drive tenis meja usia dini yang valid dan reliabel dengan menggunakan model pengembangan.

Model pengembangan yang digunakan dalam penelitian ini menggunakan metode penelitian dan pengembangan atau sering disebut (research and development). Dasar pertimbangan jenis penelitian dan pengembangan yang digunakan untuk mengembangkan model instrumen penilaian keterampilan forehand dan backhand tenis meja pada atlet usia dini di Yogyakarta, karena jenis penelitian dan pengembangan ini berorientasi pada produk. Melalui penelitian dan pengembangan diharapkan dapat menjembatani kesenjangan penelitian yang lebih banyak menguji teori ke arah menghasilkan produk-produk yang langsung digunakan oleh pengguna.

\section{Prosedur Pengembangan}

Prosedur pengembangan yag diadaptasi dari Borg \& Gall secara garis besar dibagi menjadi dua tahap yaitu: tahap sudi pendahuluan dan tahap pengembangan. Dalam studi pendahuluan dilakukan dengan dua betuk, yaitu studi pustaka dan studi lapangan. Studi pustaka dengan cara mengkaji teori, literatur, dan hasil penelitian yang relevan, studi lapangan dilakukan dengan cara melakukan observasi di lapangan untuk mengetahui kondisi nyata di lapangan sebagai tempat berlangsungnya aktivitas yang akan diteliti.

Dalam tahap pengembangan ada tiga langkah yang dilakukan yaitu: draf awal yang divalidasi ahli, uji coba skala kecil dengan tujuan untuk mencari kelemahan dan kekurangan produk, uji coba skala besar dengan tujuan untuk pemantapan instrumen.

Perencanaan dan pengembangn draf awal instrumen penialian teknik meliputi: analisis produk yang dikembangkan yaitu analisis instrumen penilaian teknik forehand dan backhand, mendefinisikan konstrak yaitu teknik forehand dan backhand, menetapkan indikator teknik forehand dan backhand, menetapkan deskripsi dari setiap indikator sebagai pedoman observasi, menetapkan tugas teknik forehand dan backhand, menetapkan lembar observasi, menetapkan skala penyekoran, menyusun rancangan draf instrumen penilaian teknik forehand dan backhand.

Rancangan produk awal instrumen penilaian teknik, sebelum diujicobakan perlu dilakukan validasi oleh para ahli sesuai dengan bidangnya yaitu 1 orang pakar penilaian, 2 pakar tenis meja dan 2 pelatih tenis meja. Para pakar yang ditunjuk. Bukti dari validitas isi didapat melalui kesepakatan dari para ahli (exper judgment) terhadap instrumen penilaian yang digunakan. Validasi empirik dilakukan dengan cara uji coba lapangan. Uji coba ini dilakukan untuk mendapatkan masukan saran serta revisi produk, sehingga nantinya dapat menghasilkan model penilaian teknik forehand dan backhand tenis meja sesuai dengan atlet usia dini dan digunakan untuk menguji keandalan validitas dan reliabilitas antarrater instrumen penilaian yang dikembangkan. Uji coba dilakukan sekala kecil dan skala besar.

Pada penelitian ini melibatkan lima rater, setiap rater diminta untuk mengobservasi dan menilai atlet dalam keterampilan teknik forehand dan backhand tenis meja atlet pemula. Harapan yang ingin dicapai oleh peneliti dari ke lima pengamat ini adalah agar ketiganya tidak memiliki perbedaan yang signifikan. Hasil dari masing-masing pengamat akan diuji korelasi antar pengamat (interrater reliability) sehingga koefisien reliabilitas yang didapat akan menunjukkan tingkat konsistensi antarrater. Dengan demikian indeks kehandalan dalam uji coba ini adalah indeks kehandalan interrater.

Untuk memperjelas prosedur pengembangan instrumen penilaian teknik forehand 
berikut ini:

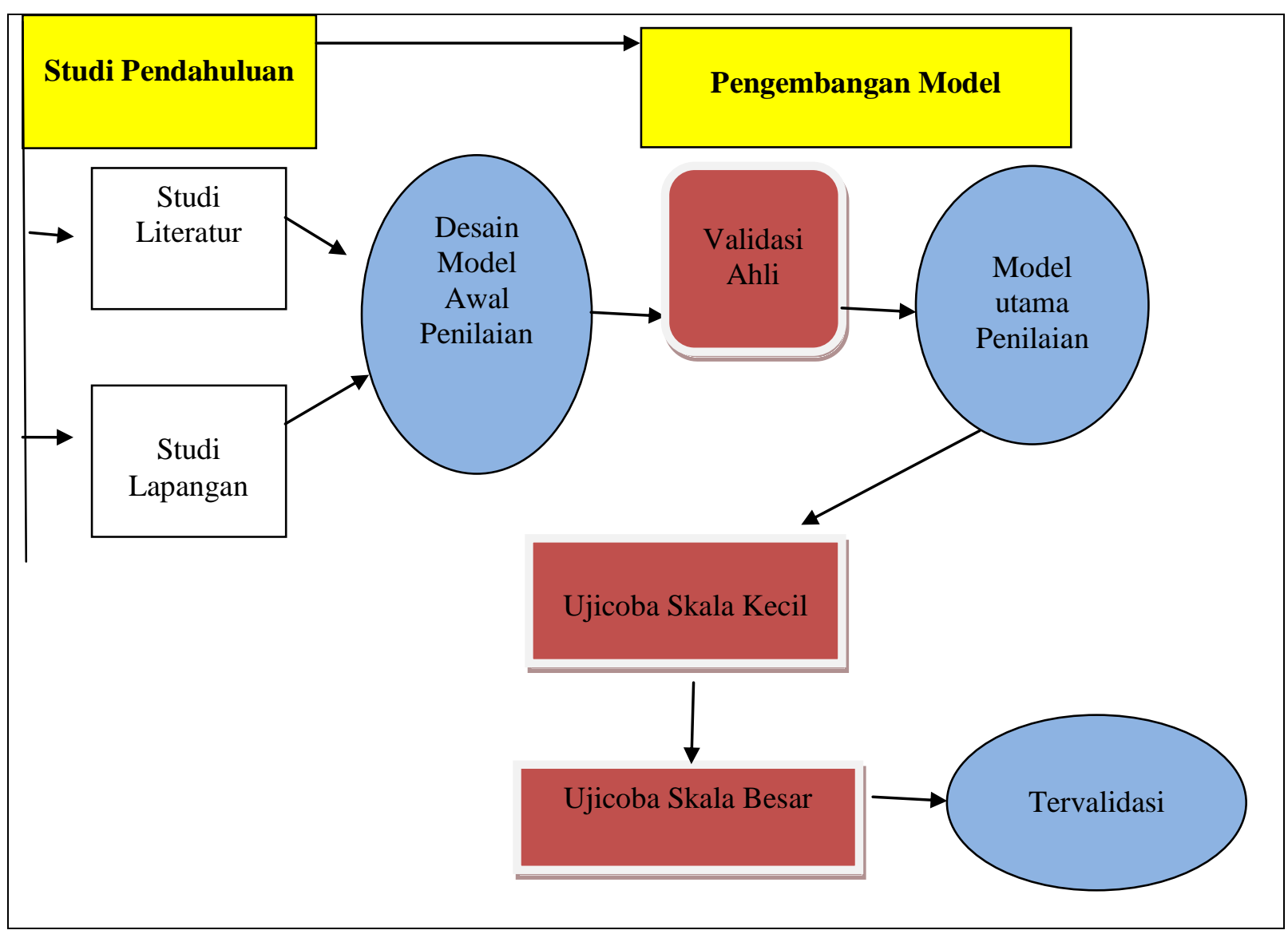

Gambar 1. Prosedur Pengembangan Model Penilaian Tehnik Forehand dan Backhand Tenis meja Usia Dini.

Subjek Penelitian

Subjek untuk mengembangkan instrumen penilaian teknik forehand dan backhand adalah atlet tenis meja usia dini di Yogyakarta.

\section{Jenis Data}

Data yang digunakan dalam penelitian ini terdiri dari data kuantitatif dan kualitatif. Data kualitatif digunakan untuk mengembangkan konstruk instrumen penilaian teknik forehand dan backhan. Data kualitaif diperoleh melalui para pakar tenis meja. Data kuantitatif digunakan untuk memperoleh koefesiensi keandalan instrumen, data kuantitatif diperoleh dari hasil penilaian atlet yang dilakukan oleh pelatih tenis meja.

\section{Waktu dan Tempat Penelitian}

Penelitian ini dilaksanakan pada bulan November-Desember 2012 di PTM TT-27 Yogyakarta.

\section{Teknik Analisis Data}

Analisis data yang dilakukan pada penelitian ini memfokuskan pada pegujian hasil dari para penilai, untuk dapat keyakinan dari instrumen penilaian keterampilan teknik forehand dan backhan drive tenis meja pada atlet pemula. Instrumen penilaian akan dikatakan baik apabila mempunyai validitas dan reliabilitas. Validitas yang tinggi mencerminkan sejauh mana ketepatan dan kecermatan alat ukur tersebut dalam melakukan fungsi ukurnya. Reliabilitas yang tinggi mencerminkan sejauh mana pengukuran dapat dipercaya.

Pengujian validitas isi instrumen penilaian teknik forehand dan backhand dilakukan melalui pendapat para pakar bidang olahraga tenis meja dengan menggunakan rumus CVR (content validity ratio) dengan rumus CVR $=(2$ $\mathrm{Mp} / \mathrm{M})-1$.

Pengujian reliabilitas dalam instrumen penilaian ini menggunakan consistency alpha crobanch, yang memberikan syarat bahwa suatu instrumen dapat dikatakan reliabel apabila hasil 
penghitungannya menunjukkan nilai $>0,75$. Untuk mencari reliabilitas instrumen maka yang harus dilakukan oleh seorang penenliti adalah mengumpulkan data, kemudian menganalisis item, di mana masing-masing skor item dikorelasikan dengan skor total.

Reliabilitas antarrater menggunakan ICC (Interclass Corelation Coeffisients) dari Kappa, karena menggunakan lebih dari dua rater. Penentuan reliabilitas dari kriteria instrumen penilaian teknik forehand dan backhan dilakukan dengan uji koefisiensi korelasi antar kelas (Intraclass Correlation Coeffisients/ICC). Koefesien interrater adalah salah satu sarana untuk melihat tingkat konsisten atau kestabilan antar rater dalam memberikan rating terhadap unjuk kerja permainan tenis meja.

\section{Hasil Penelitian dan Pembahasan}

Dalam proses pembuatan instrumen penilaian diperlukan analisis kebutuhan yang bertujuan untuk mengetahui apakah instrumen yang akan disusun benar-benar dibutuhkan dalam pembinaan tenis meja khususnya di Kota Yogyakarta. Apabila analisis yang dilakukan sesuai dengan yang dibutuhkan, maka pembuatan instrumen tersebut layak sehingga dapat dilanjutkan dengan menyusun rencana penelitian.

Hasil studi pendahuluan menggunakan angket atau wawancara yang dilakukan terhadap pelatih sebagai subjek penelitian tahap analisis kebutuhan. Hasil diperoleh informasi aspek-aspek penilian kegiatan latihan teknik forehand dan backhand tenis meja. Analisis kebutuhan dilakukan dengan cara melakukan studi pendahuluan, memberikan angket kepada pelatih yang ada di Kota Yogyakarta, dan peneliti melakukan terhadap 10 pelatih tenis meja. Terdapat empat pertanyaan beserta hasilnya dalam bidang kepelatihan, yaitu sebagai berikut:

Apakah Anda melakukan penilaian keterampilan di setiap latihan? (a) Ya, (b) Tidak

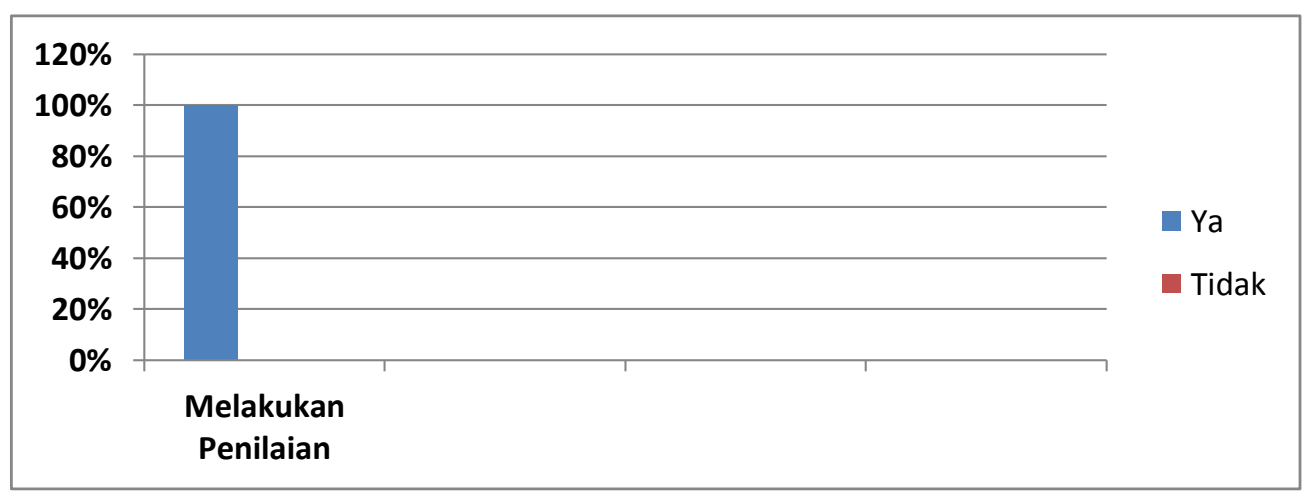

Gambar 2. Diagram hasil studi pendahuluan

Dari diagram tersebut dapat disimpulkan bahwa dari 10 pelatih menyatakan bahwa $100 \%$ melakukan penilaian di setiap akhir latihan.
Apakah penilaian yang anda lakukan sudah mencakup segi teknik, dan sikap? (a) Sudah, (b) Belum

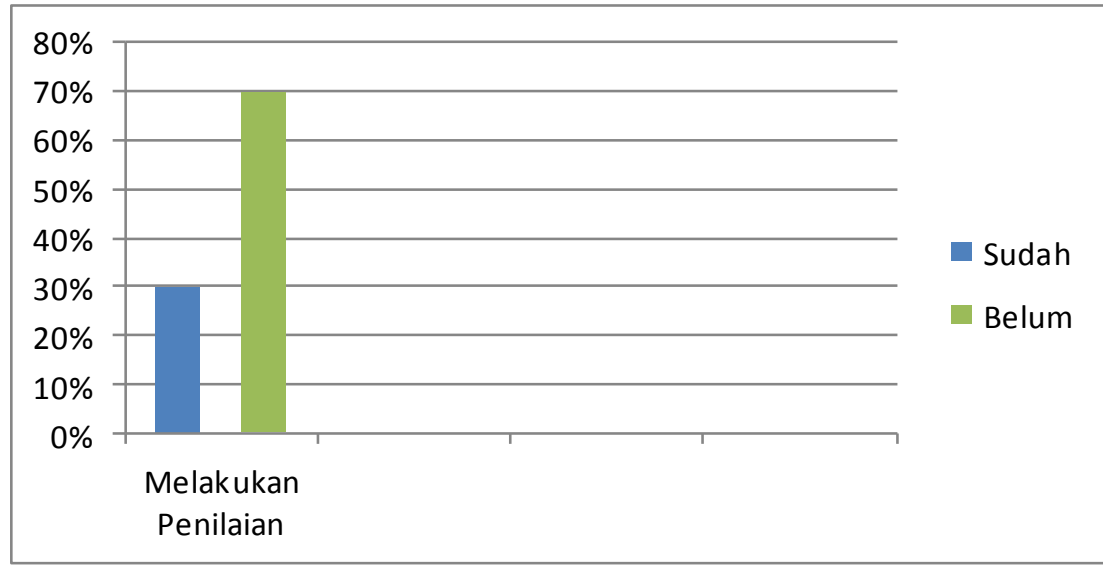

Gambar 3. Diagram hasil studi pendahuluan 
Dari diagram 3 tersebut maka dapat disimpulkan bahwa dari 10 pelatih $30 \%$ menyatakan sudah menilai dalam segi teknik dan sikap dan $70 \%$ menyatakan baru melakukan penilaian yang mencakup teknik saja.
Apakah anda pernah melakukan penilaian dengan menggunakan instrumen? (a) Pernah, (b) Belum

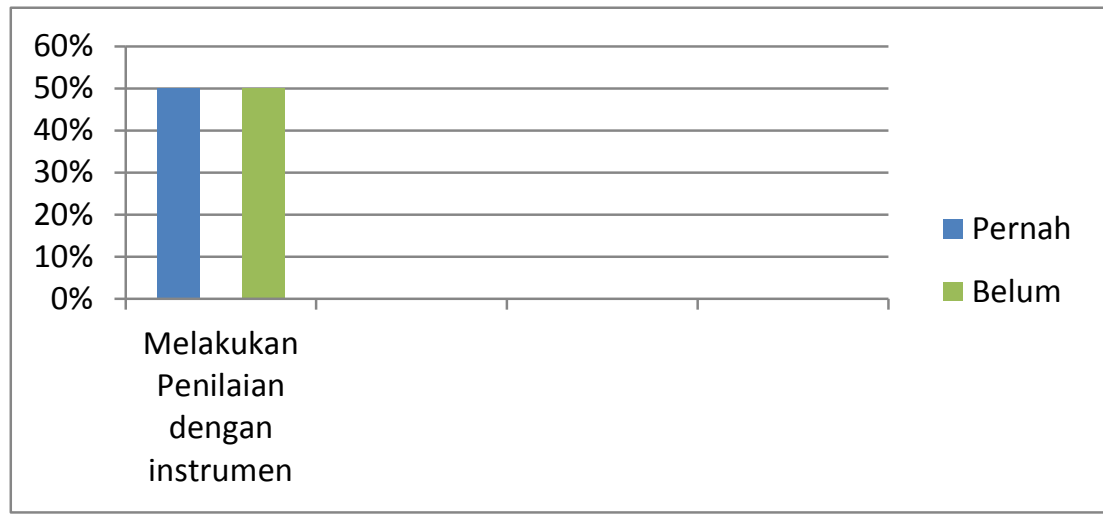

Gambar 4. Diagram hasil studi pendahuluan

Dari gambar 4 tersebut, maka dapat disimpulkan bahwa dari 10 pelatih $50 \%$ meyatakan melakuan penilaian dengan menggunakan instrumen, dan 50\% melakukan tanpa instrumen.
Apakah anda memerlukan instrumen untuk menilai keterampilan teknik? (a) Memerlukan (b) Tidak memerlukan

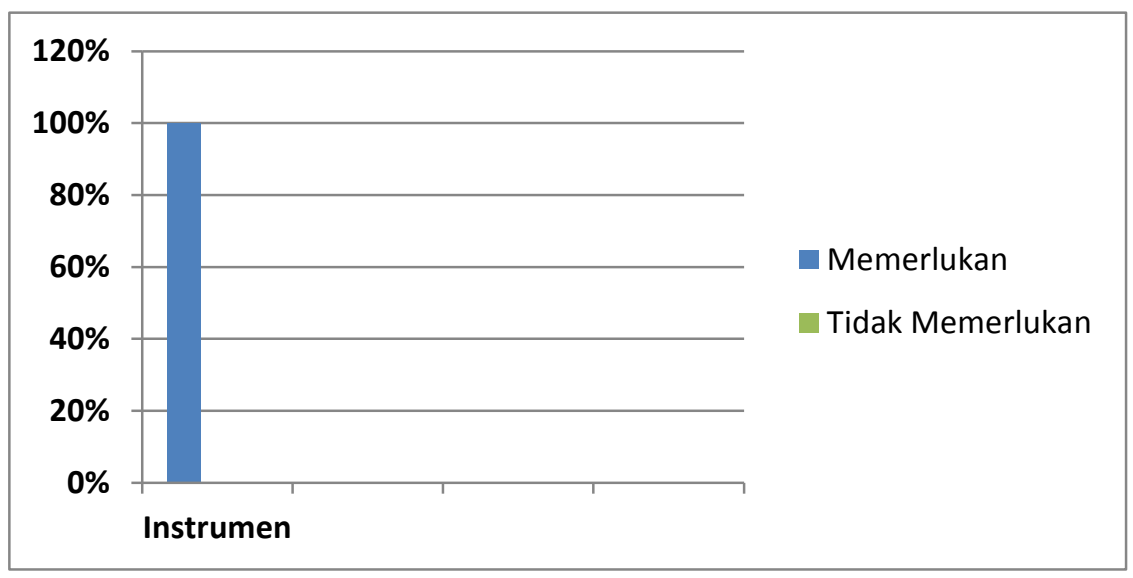

Gambar 5. Diagram hasil studi pendahuluan

Dari gambar 5 tersebut, maka dapat disimpulkan bahwa dari 10 pelatih $100 \%$ menyatakan memerlukan instrumen untuk melakukan penilaian untuk atlet.

Berdasarkan kajian pustaka, analisis kebutuhan dan penelitian yang relevan maka dapat disusun draf awal instrumen penilaian teknik forehand dan backhand yang berisi tentang: (1) mengidentifikasi aspek proses unjuk kerja yang akan dinilai, (2) menyususun kisi-kisi berdasarkan indikator, (3) pedoman penilaian dan pengamatan (4) menyusun lembar tugas dan petunjuk pelaksanaan atlet, lembar observasi serta penyekorannya.

Draf yang telah tersusun selanjutnya di uji validasi kepada lima pakar yang telah ditunjuk dan mendapat masukan dan saran dari para pakar. Hasil penilaian dari para pakar sebagai berikut;

Tabel 1. Hasil Validasi Ahli

\begin{tabular}{ccc}
\hline Pakar & Nilai & Keterangan \\
\hline 1 & 4 & Baik \\
2 & 4 & Baik \\
3 & 3 & Baik \\
4 & 4 & Baik \\
5 & 3 & Baik \\
\hline
\end{tabular}

Dari hasil penilaian yang telah dilakukan oleh para pakar selanjutnya dilakukan penghitungan validitas isi dengan menggunakan rumus $\mathrm{CVR}=(2 \mathrm{Mp} / \mathrm{M})-1 . \mathrm{MP}$ adalah jumlah pakar yang memberikan nilai baik atau 
dengan penilaian 3-4, M adalah jumlah pakar. I hasil validasi yang lakukan para ahli, lima pakar memberikan nilai baik terhadap draf instrumen penilaian yang dikembangkan. Hasil validitas isi yang diperoleh dengan menggunakan rumus tersebut adalah 1 , sehingga dari hasil penilaian yang dilakukan oleh para ahli maka dapat dikatakan instrumen yang disusun dapat dilanjutkan ke tahap selanjutnya setelah direvisi sesuai dengan saran dari para ahli. Saran dan masukan dari para ahli dapat dilihat pada tabel 2 berikut ini;

Tabel 2. Saran dari para ahli

\section{Forehand}

1. Pada lembar tugas harus lebih dijabarkan sehingga para pelatih yang akan menggunakan akan lebih jelas.

2. Pada saat pelaksanaan yang menjadi pengumpan bukan sesama atlet tetapi pelatih (orang yang lebih mahir).

3. Siswa/atlet melakukan pukulan dengan waktu (150 detik).

4. Pelaksanaan penilaian dengan cara 50 detik pertama menilai sikap awal, 50 detik kedua menilai pelaksanaan, 50 detik terakhir menilai gerak lanjutan.

5. Pada posisi sikap awal selain lutut ditekuk posisi badan juga harus sedikit condong ke depan.

6. Pada tahap pelaksanaan putar tubuh dan tangan ke belakang dilakukan dalam waktu yang bersamaan.

7. Pada pedoman penilaian indikator yang akan dinilai dari tiap-tiap aspek jumlah poin-poin harus dibuat sama.

8. Berikan skala penilaian.

9. Cantumkan peralatan yang digunakan.

Instrumen penilian yang telah disetujui oleh para pakar kemudian digunakan dalam uji coba skala kecil terhadap 3 orang pelatih dan 3 orang atlet. Uji coba skala kecil dilakukan di PTM TT27 pada tanggal 25 november 2012. Setelah peneliti mempunyai instrumen penilaian teknik forehand dan backhand drive selanjutnya dilakukan validasi empirik yaitu dengan uji skala kecil kemudian berlanjut ke uji skala besar. Uji coba skala kecil ini dilakukan untuk mengetahui kelemahan dari insrtumen penilaian yang dikembangkan, serta dasar untuk melakukan revisi produk sebelum dilakukan uji skala besar dan kemudian menjadi produk akhir. Hal

\section{Backhand}

1. Siswa/atlet melakukan pukulan dengan waktu 150 detik, 50 detik pertama dinilai sikap awal, 50 detik kedua menilai pelaksanaan, 50 detik ketiga menilai gerak lanjutan.

2. Dalam pelaksanaannya yang menjadi pasangan atlet adalah pelatih.

3. Pada siakap awal kedua kaki sedikit sejajar.

4. Pada sikap akhir bet ditarik kembali ke belakang dan berhenti di depan badan.

5. Pada pedoman penilaian indikator yang akan dinilai dari tiap-tiap aspek jumlah poin-poin harus dibuat sama.

6. Berikan skala penilaian. ini dilakukan untuk mendukung agar instrumen yang dikembangkan menjadi reliabel.

\section{Uji Coba Skala kecil}

Uji coba skala kecil menggunakan tiga penilai (rater) dengan 3 atlet tenis meja. Hasil data dari ketiga rater dianalisis untuk mengetahui validitas dan reliabilitas antarrater instrumen penilaian teknik forehand. Berdasarkan uji statistik reliabilitas antarrater data uji coba skala kecil menggunakan Crobanch Alpha, adapun hasil dari uji coba skala kecil penilaian teknik forehand dan backhand drive dari masing-masing indikator adalah secara garis besarnya seperti tabel 3 .

Tabel 3. Hasil Uji Reliabilitas Intrumen dan Hasil Interclass Correlation Coefisiensi (ICC) Teknik Forehand dan Backhand.

\begin{tabular}{lcccc}
\hline \multirow{2}{*}{ Indikator } & \multicolumn{2}{c}{ Forehand } & \multicolumn{2}{c}{ Backhand } \\
\cline { 2 - 5 } & reliabilitas & ICC & Reliabilitas & ICC \\
\hline Sikap awal & $\mathrm{r}=0,957$ & $\mathrm{r}=0,882$ & $\mathrm{r}=0,962$ & $\mathrm{r}=0,895$ \\
Pelaksanaan & $\mathrm{r}=0,938$ & $\mathrm{r}=0,833$ & $\mathrm{r}=0,938$ & $\mathrm{r}=0,833$ \\
Gerak lanjutan & $\mathrm{r}=0,938$ & $\mathrm{r}=0,895$ & $\mathrm{r}=0,938$ & $\mathrm{r}=0,833$ \\
\hline
\end{tabular}

Berdasarkan tabel 3 tersebut, maka dapat disimpulkan bahwa teknik forehand dan backhand drive mempunyai reliabilitas yang tinggi. Dalam analisis menggunakan interclass correlation coefisiensi (ICC), nilai koefisien reliabilitas antarrater korelasi interclass teknik forehand drive dihasilkan nilai reliabilitas antarrater yang tinggi. 
Dengan demikian, penghitungan statistik reliabilitas, uji coba skala kecil teknik forehand dan backhand drive mempunyai reliabilitas antarrater yang tinggi, sehingga semua teknik dari tiap-tiap indikator dinyatakan reliabel dan selanjutnya dapat digunakan untuk uji coba skala besar.

\section{Uji Coba Skala Luas}

Untuk memantapkan instrumen penilaian unjuk kerja teknik forehand dan backhand setelah perbaiiki pada skala kecil, maka selanjutnya dilakukan uji coba lapangan yaitu skala luas. Uji coba skala dilakukan untuk mengetahui validitas dan reliabilitas instrumen.

Dari uji coba skala besar dengan menggunakan test-retest untuk menguji validitas instrumen penilaian memperoleh hasil seperti pada tabel 4 berikut:
Tabel 4. Hasil Validitas Instrumen

\begin{tabular}{cc}
\hline Forehand & Backhand \\
\hline 0,915 & 0,921 \\
\hline
\end{tabular}

Dari tabel 4 tersebut dapat disimpulkan bahwa hasil validitas instrumen penilaian teknik forehand dan backhand memiliki validitas yang tinggi. Sehingga pengembangan instrumen penilaian keterampilan teknik tenis meja ini mempunyai validias dan reliabilitas yang tinggi. Dapat disimpulkan bahwa hasil penghitungan statistik dari instrumen penilaian teknik forehand dan backhand drive mempunyai nilai koefisien yang tinggi, sehingga dapat digunakan sebagai standar penilaian teknik forehand dan backhand drive untuk atlet usia dini.

Hasil data dari kelima rater dianalisis reliabilitasnya secara lengkap. Hasil reliabilitas antarrater instrumen penilian unjuk kerja teknik forehand secara garis besarnya seperti tabel 5 berikut;

Tabel 5. Hasil Uji Coba Skala besar

\begin{tabular}{ccccc}
\hline \multirow{2}{*}{ Indikator } & \multicolumn{2}{c}{ Forehand } & \multicolumn{2}{c}{ Backhand } \\
& Reliabilitas & ICC & Reliabilitas & ICC \\
\hline Sikap awal & $\mathrm{r}=0,975$ & $\mathrm{r}=0,886$ & $\mathrm{r}=0,961$ & $\mathrm{r}=0,831$ \\
Pelaksanaan & $\mathrm{r}=0,961$ & $\mathrm{r}=0,830$ & $\mathrm{r}=0,974$ & $\mathrm{r}=0,881$ \\
Gerak lanjutan & $\mathrm{r}=0,955$ & $\mathrm{r}=0,808$ & $\mathrm{r}=0,989$ & $\mathrm{r}=0,945$ \\
\hline
\end{tabular}

Berdasarkan tabel 5 tersebut maka dapat disimpulkan bahwa hasil dari uji coba skala besar penilaian teknik forehand dan backhand drive menghasilkan data yang dianalisis menggunakan uji statistik dan menghasilkan reliabilitas antar rater yang tinggi, sehingga produk tersebut valid dan reliabel sehingga dapat digunakan untuk penilaian dalam membantu proses evaluasi hasil latihan atlet. Prroduk hasil dari pengembangan dapat dilihat pada tabel berikut ini;

Tabel 6. Lembar Tugas Atlet Tes Keterampilan Forehand

\begin{tabular}{ll}
\hline No & \multicolumn{1}{c}{ Tugas Siswa/Atlet } \\
\hline 1. & Atlet mengambil posisi untuk memukul bola dengan diumpaan oleh pelatih. \\
2. & Bola pertama dipukul oleh pengumpan. \\
3. & Bila ada aba-aba "yak" bola pertama mulai dipukul oleh pengumpan. \\
4. & Atlet melakukan pukulan stroke/rally selama $3 \times 50$ detik. \\
5. & Setiap atlet melakukan pukulan forehand drive secara diagonal \\
6. & Setiap atlet memukul hanya dengan menggunakan forehand drive \\
7. & Jika bola keluar dari lapangan pengumpan segera mengambil bola dan melanjutkan mengumpan kepada \\
& testi. \\
8. & Bila ada aba-aba "STOP" pukulan dihentikan. \\
\hline
\end{tabular}


Tabel 7. Pedoman Penilaian Teknik Forehand

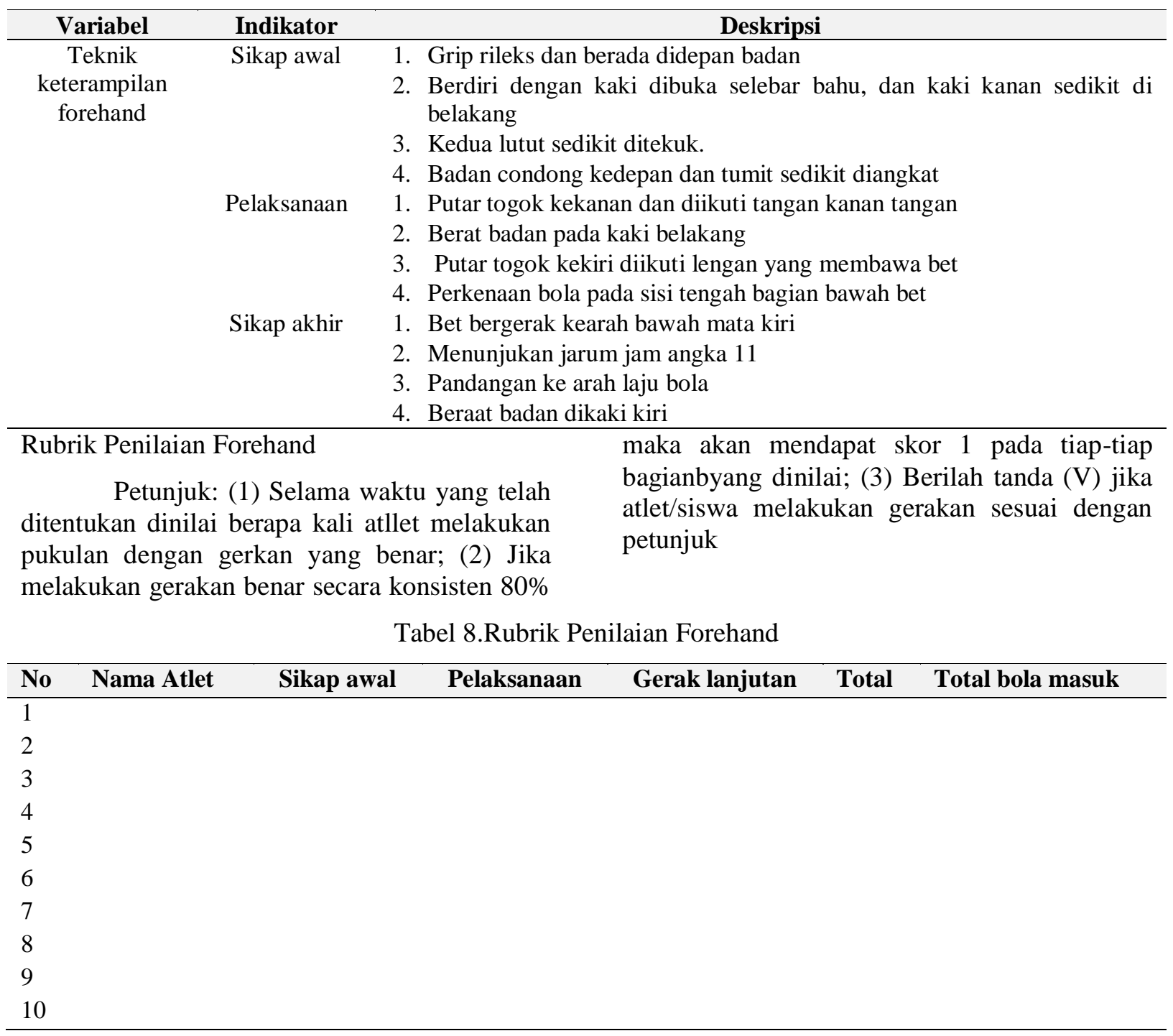

Tabel 9. Lembar Tugas Atlet Tes Keterampilan Backhand

\begin{tabular}{cl}
\hline No & \multicolumn{1}{c}{ Tugas Siswa/Atlet } \\
\hline 1. & Atlet mengambil posisi untuk memukul bola dengan diumpaan oleh pelatih. \\
2. & Bola pertama dipukul oleh pengumpan. \\
3. & Bila ada aba-aba "yak" bola pertama mulai dipukul oleh pengumpan. \\
4. & Atlet melakukan pukulan stroke/rally selama 150 detik. \\
5. & Setiap atlet melakukan pukulan backhand drive secara diagonal \\
6. & Setiap atlet memukul hanya dengan menggunakan backhand drive \\
7. & Jika bola keluar dari lapangan pengumpan segera mengambil bola dan melanjutkan mengumpan kepada \\
& testi. \\
8. & Bila ada aba-aba "STOP" pukulan dihentikan. \\
\hline
\end{tabular}


Tabel 10.Pedoman Penilaian Keterampilan Teknik Backhand

\begin{tabular}{ccl}
\hline VARIABEL & INDIKATOR & \multicolumn{1}{c}{ DESKRIPSI } \\
\hline Teknik & Sikap awal & 1. Grip rileks dan berada didepan badan \\
keterampilan & & 2. Berdiri dengan kaki dibuka selebar bahu \\
backhand & & 3. Kedua lutut sedikit ditekuk. \\
& 4. Badan condong ke depan \\
& 1. Lengan yang membawa bet ditarik kebelakang mendekati tubuh \\
& 2. Bet berada didepan tubuh dengan berat badan di kaki kiri \\
& 3. Ayunkan lengan yang membawa bet kedepan diikuti. \\
& 4. Pukul dan dorong bola dengan perkenaan di bagian tengah agak \\
& Pelaksanaan & 1. Gerakan bet. \\
& 2. Bet menunjukan jarum jam angka 1. \\
& 3. Pandangan ke arah laju bola \\
& 4. Berat badan di kaki kanan
\end{tabular}

Sikap akhir

\section{Rubrik Penilaian Backhand}

Petunjuk: (1) Selama waktu yang telah ditentukan dinilai berapa kali atlet melakukan pukulan dengan gerkan yang benar; (2) Jika melakukan gerakan benar secara konsisten $80 \%$ maka akan mendapat skor 1 pada tiap-tiap bagianbyang dinilai; (3) Berilah tanda (V) jika atlet/siswa melakukan gerakan sesuai dengan petunjuk.

Tabel 11. Rubrik Penilaian Backhand

\begin{tabular}{|c|c|c|c|c|c|c|}
\hline No & Nama Atlet & Sikap awal & Pelaksanaan & Gerak Lanjutan & Total & Total Bola Masuk \\
\hline 1 & & & & & & \\
\hline 2 & & & & & & \\
\hline 3 & & & & & & \\
\hline 4 & & & & & & \\
\hline 5 & & & & & & \\
\hline 6 & & & & & & \\
\hline 7 & & & & & & \\
\hline 8 & & & & & & \\
\hline 9 & & & & & & \\
\hline 10 & & & & & & \\
\hline
\end{tabular}

Setelah produk tersebut dilakukan uji skala besar dan memperoleh hasil instrumen penilaian yang valid dan reliabel selanjutnya dilakukan uji keefektifan instrumen untuk mengetahui instrumen penilaian teknik forehand dan backhand drive efektif untuk meningkatkan motivasi atlet untuk berlatih, maka setelah atlet melakukan tes atlet diberi angket dengan indikator sebagai berikut senang dan keinginan berlatih sehingga menambah motivasi atlet.

Dari hasil uji keefektifan yang dilakukan terhadap 10 atlet yang dilakukan penilaian dengan menggunakan instrumen forehand dan backhand ini diperoleh hasil seperti gambar 6 berikut: 


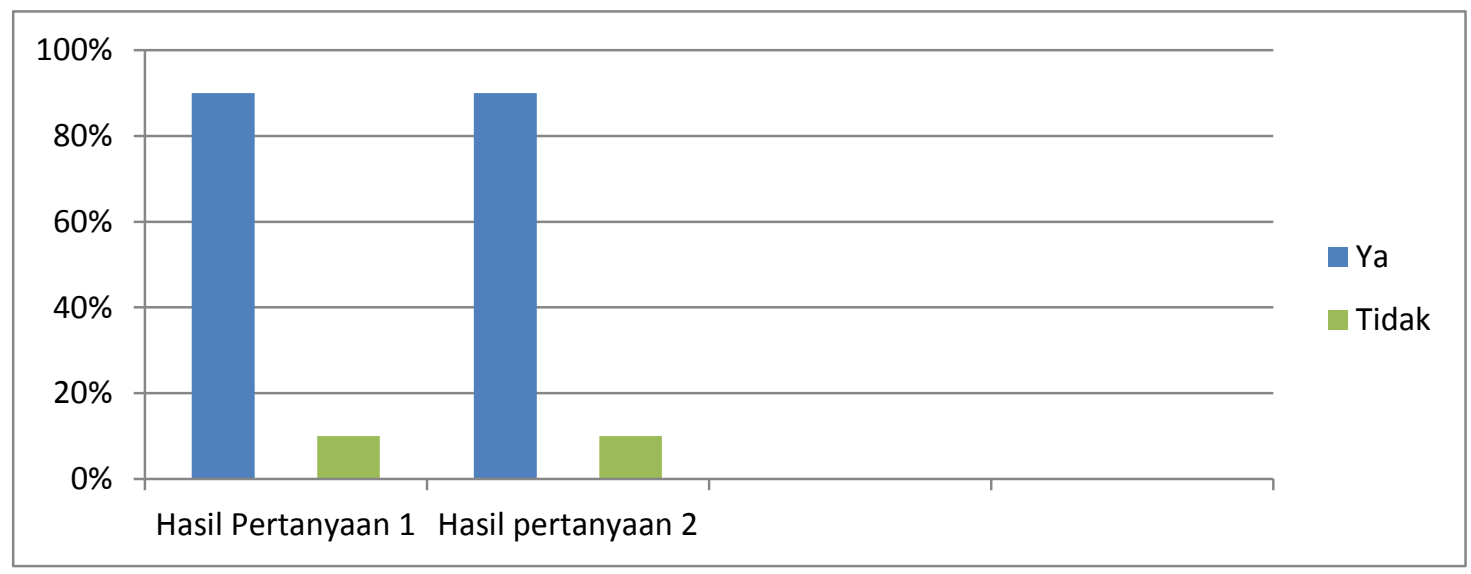

\section{Gambar 6. Hasil Uji Keefektifan}

Berdasarkan gambar tersebut dapat disimpulakan atlet yang melakukan tes dengan menggunakan instrumen penilaian teknik forehand dan backhand drive merasa senang melakukan tes $90 \%$, dan $10 \%$ merasa tidak senang. Demikian pula dengan atlet yang menyatakan ingin berlatih lebih giat setelah melakukan tes menggunakan instrumen penilaian teknik forehand dan backhand drive menyatakan $90 \%$ menyatakan ingin meningkatkan latihan lebih giat lagi dan $10 \%$ tidak ingin meningkatkan latihan. Kesimpulannya instrumen yang dikembangkan efektif untuk meningkatkan minat berlatih atlet, karena atlet lebih termotivasi untuk berlatih lebih giat lagi.

Pengembangan instrumen penilaian setelah melakukan proses pembuatan, validasi ahli, uji coba, revisi dan uji keefektifan akhirnya dihasilkan sebuah instrumen penilaian keterampilan teknik forehand dan backhand drive tenis meja untuk atlet usia dini yang valid dan reliabel, indikator-indikator dari masing-masig teknik yang dinilai adalah sebagai berikut: sikap awal, pelaksanaan, gerak lanjutan.

Produk akhir yang dihasilkan dalam penelitian ini berupa instrumen penilaian teknik forehand dan backhand drive tenis meja untuk atlet usia dini, yang didalamnya terdapat petunjuk penggunaan, lembar tugas siswa, pedoman penilaian, rubrik penilaian, serta tabel penyekoran.

\section{Simpulan dan Saran}

Simpulan

Pertama, tersusun komponen-komponen dalam pelaksanaan penilaian teknik forehand drive, serta tersusun komponen-komponen dalam pelaksanaan penilaian teknik backhand drive tenis meja untuk atlet usia dini yang dapat digu-nakan sebagai pedoman penilaian. Kedua, tersusun komponen-komponen penilaian tersebut terdiri dari sikap awal, pelaksana-an dan sikap akhir. Ketiga, tersusun instrumen penilaian kemampuan teknik forehand drive untuk atlet usia dini yang valid dan reliabel. Keempat, tersusun instrumen kemampuan teknik backhand drive untuk atlet usia dini yang valid dan reliabel. Kelima, telah tersusun instrumen penilaian teknik forehand dan backhand drive yang efektif. Atlet usia di merasa senang dan lebih termotivasi untuk lebih giat berlatih lagi. Hal ini dikarenakan atlet usia dini merasa senang ketika dilakukan penilaian dan atlet tersebut ingin lebih baik nilainya dari teman-temannya, sehingga menambah motivasi bagi atlet. Dengan demikian instrumen penilaian ini efektif untuk digunakan kepada atlet usia dini tenis meja, maka intrumen ini dapat digunakan sebagai pedoman dalam menilai teknik forehand dan backhand drive tenis meja.

Saran

Pertama, Pelaksanaan penilaian membutuhkan konsentrasi dan keseriusan dari para penilai, oleh karena itu perlu adanya pembatasan baik dari segi waktu dan jumlah penilai. Kedua, instrumen penilaian ini dapat digunakan oleh pelatih tenis meja dalam melakukan penilaian hasil latihan. Ketiga, instrumen penilaian ini dapat membantu pelatih dalam melakukan evaluasi terhadap atlet. Keempat, untuk pengembangan lebih lanjut dapat dilakukan penilaian keterampilan teknik dengan merekam praktik yang dilakukan atlet, sehingga pengamatan dapat lebih cermat, dan tepat. 


\section{Daftar Pustaka}

Arikunto, Suharsimi. (2001). Prosedur penelitian suatu pendekatan praktek. Yogyakarta: Rineka Cipta.

Borg, W \& Gall, M.D. (1983). Education research. New York. Interstate book manufactures.

Harlen, W. (2007). Assesing of learning: Sage Publication.

Merdapi, Djemari dkk (2005). Pengembangan instrumen penelitian pendidikan. Buku Pegangan Kuliah, tidak diterbitkan. Yogyakarta: PPS UNY.

Miller, David K (2002) Measurement by the physical educator, why and how, fourth edition. New York: Ny Mc. Graw Hil

Payne, D.A. (2003). Applied education assesment, $\left(2^{\text {nd }}\right.$ ed). Canada: Wadsworth/ Thomson Learning
Rachman, Hari Amirullah. (2007). Pengembangan alat evaluasi keterampilan softball berbasis authentic asessment. Majalah Ilmiah Olahraga, Volume 13, Nomer 3, hal 270-296.

Sudjana, Nana. (2005). Penilaian hasil proses belajar mengajar. Bandung: Remaja Rosdakarya Offset.

Sukadiyanto. (2002). Pengantar teori dan metode melatih fisik petenis. Yogyakarta: FIK Universitas Negeri Yogyakarta.

Sukadiyanto. (2005). Pengantar teori dan metodologi melatih fisik. Yogyakarta: PKO FIK UNY.

Tomoliyus. (2012). Panduan kepelatihan tenis meja bagi sekolah dasar. Makalah. Yogyakarta: FIK UNY.

Zainul \& Nasution. (2001). Penilaian hasil belajar. Jakarta: Dirjen Dikti. 